\title{
UPAYA PENANGGULANGAN COVID 19 DENGAN PEMANFAATAN LAHAN PEKARANGAN RUMAH SEBAGAI MEDIA TANAMAN OBAT HERBAL DESA SUNGAI ILIRAN /KECAMATAN GAUNG ANAK SERKA/KABUPATEN INDRAGIRI HILIR/PROVINSI RIAU.
}

Hidayati

'Jurusan Pertanian, Fakultas Pertanian, Universitas Islam Indragiri

Email: aida87794@gmail.com

\begin{abstract}
The period of the COVID-19 pandemic forces everyone to stay at home to break the chain of spreading the virus. This condition does not necessarily make farmers unproductive. Various activities can be carried out, especially those that can support household food needs. One thing that can be done is gardening herbal medicinal plants in the yard of the house. The most important aspect in the use of this house yard is that the plants from farming in the home page can meet consumption and sales needs as well as a more beautiful and healthier yard environment during the Covid 19 period. From the results of observations and interviews with related parties, it can be seen that the main problem of farmers in farming in the home yard is the limited land available and also the limited number of harvests and the non-diverse varieties of plants. This report was conducted in: Sungai Iliran Village / Gaung Anak Serka Subdistrict / Indragiri Hilir Regency / Riau Province, the type of research used is descriptive qualitative research. The research conducted in August - September 2020 was vulnerable for 45 days. What was used as a sample in a population of 5 people and the determination was taken based on the Bailey method (survey) is a research method in which the data collection technique was carried out through written or oral questions. From the results of interviews with several farmers and the head of the farmer groups.
\end{abstract}

Keywords: Covid 19, the yard, farmers, consumption, sales

\begin{abstract}
Abstrak
Masa pandemi COVID-19 memaksa setiap orang untuk tinggal di rumah demi memutus mata rantai penyebaran virus. Kondisi ini tidak serta merta membuat para petani menjadi tidak produktif. Beragam aktivitas bisa dilakukan, khususnya yang bisa menopang kebutuhan pangan rumah tangga. Salah satu yang bisa dilakukan adalah berkebun tanaman obat herbal di pekarangan rumah. Aspek terpenting dalam pemanfaatan pekarangan rumah ini adalah tanaman hasil dari bertani di halaman rumah dapat memenuhi kebutuhan konsumsi maupun penjualan serta lingkungan halaman yang lebih indah dan sehat pada masa covid 19 ini. Dari hasil observasi dan wawancara dengan pihak-pihak terkait, dapat diketahui bahwa permasalahan utama petani dalam bertani di pekarangan rumah yaitu keterbatasan lahan yang ada dan juga jumlah panen yang terbatas serta varietas tanaman yang tidak beragam. Laporan ini dilakukan di :Desa Sungai Iliran /Kecamatan Gaung Anak Serka/Kabupaten Indragiri Hilir/Provinsi Riau, jenis penelitian ini digunakan adalah penelitian diskriptif kualitatif. Penelitian yang dilakukan pada bulan agustus - september 2020 dalam rentan waktu selama 45 hari. Yang di jadikan sampel dalam penelitian 5 orang populasi dan penetapan di ambil berdasarkan metode bailey (survey) merupakan satu metode penelitian yang teknik pengambilan datanya dilakukan melalui pertanyaan tertulis maupun lisan. Dari hasil wawancara beberapa petani dan ketua kelompok tani tersebut.
\end{abstract}

Kata kunci: Covid 19 berkebun tanaman obat herbal di pekarangan rumah 


\section{PENDAHULUAN}

\section{Latar Belakang Masalah}

Masa pandemi COVID-19 memaksa setiap orang untuk tinggal di rumah demi memutus mata rantai penyebaran virus. Kondisi ini tidak serta merta membuat para petani menjadi tidak produktif. Beragam aktivitas bisa dilakukan, khususnya yang bisa menopang kebutuhan pangan rumah tangga. Salah satu yang bisa dilakukan adalah berkebun tanaman obat herbal di pekarangan rumah. Aspek terpenting dalam pemanfaatan pekarangan rumah ini adalah tanaman hasil dari bertani di halaman rumah dapat memenuhi kebutuhan konsumsi maupun penjualan serta lingkungan halaman yang lebih indah dan sehat pada masa covid 19 ini. Dari hasil observasi dan wawancara dengan pihak-pihak terkait, dapat diketahui bahwa permasalahan utama petani dalam bertani di pekarangan rumah yaitu keterbatasan lahan yang ada dan juga jumlah panen yang terbatas serta varietas tanaman yang tidak beragam.

\section{IDENTIFIKASI MASALAH}

Berdasarkan pokok permasalahan yang telah dijelaskan diatas, maka terdapat beberapa pokok persoalan sebagai berikut:

1. Bagaimana cara bertani di pekarangan rumah dapat menguntungkan masyarakat pada masa covid 19

2. Bagaimana dengan keterbatasan lahan mampu menghasilkan varietas tanaman yang beragam

\section{TINJAUAN PUSTAKA}

a. Pengertaian Pertanian Pekarangan Rumah

Pekarangan merupakan suatu lahan yang berada di sekitar rumah. Hampir semua rumah memiliki pekarangan. Ibarat sebuah bunga maka putik dan benang sari sebagai rumah sedangkan mahkota sebagai pekarangannya. Fungsi dan keberadaan saling melengkapi. Apabila dikelola dengan baik maka lahan ini dapat memberikan keuntungan bagi pemilik.

Pekarangan berfungsi sebagai pembatas lahan rumah dengan lahan lain baik lahan milik orang lain maupun lahan sendiri yang digunakan untuk keperluan lain (misal kebun). Selain fungsi tersebut, pekarangan mempunyai fungsi estetis maupun ekonomis. Halaman berfungsi estetis karena biasanya pekarangan diberi atau ditanami dengan penghias rumah seperti dekorasi atau tanaman bunga sehingga rumah kelihatan lebih indah dan asri. Nilai ekonomis berkaitan dengan kemampuan lahan pekarangan untuk menghasilkan tambahan pendapatan bagi pemilik misal dengan ditanami tanaman hortikultura (buah dan sayuran) dan budidaya ternak, unggas atau ikan.

Luas pekarangan yang umumnya sempit menjadikan lahan ini kurang dilirik untuk diusahakan secara komersial dan besar-besaran. Hanya beberapa kalangan yang melihat potensi lahan ini dengan memanfaatkan teknologi budidaya mengingat keterbatasan luas lahan. Namun demikian lahan pekarangan mempunyai beberapa kelebihan dibandingkan dengan jenis lahan lain. Kelebihan tersebut antara lain berkaitan dengan jarak yang dekat dengan rumah (pemilik) sehingga mudah diawasi dan dikelola. Selain itu ketersediaan air lebih dekat dengan sumber sehingga kebutuhan air dapat terpenuhi.

Potensi yang selama ini sudah dimanfaatkan dan masih berpeluang besar untuk dikembangkan adalah dengan menjadikan pekarangan sebagai salah satu lahan pertanian mini yang dapat dimanfaatkan untuk memenuhi kebutuhan rumah tangga (keluarga) itu sendiri. Pengaturan areal pertanaman tergantung pada kondisi pekarangan. Areal bisa dipilih di depan, belakang, samping rumah atau kombinasi.

Budidaya pekarangan tidak hanya dilakukan secara monokultur (satu jenis komoditas) namun bisa pula secara polikultur (beragam jenis komoditas). Pilihan tersebut disesuaikan dengan kemampuan dan keterampilan suatu keluarga. pekarangan untuk konservasi keanekaragaman hayati pertanian dapat juga mendukung agroekologi dan pertanian yang keberlanjutan (Marshall dan Moonen 2002).

\section{Ragam tanaman yang bisa di budidayakan pada pertanian pekarangan rumah}
a. Tanaman Sayuran
Lahan pekarangan yang kosong dapat ditanami dengan berbagai komoditas 
pertanian. Komoditas hortikultur yang umum ditanam di pekarangan adalah berbagai macam sayuran. Jenis sayuran yang dapat ditanam adalah sayuran kangkung, bayam, selada, cabai, sawi dan lain-lain. Hasil panen sayuran diutamakan untuk memenuhi kebutuhan keluarga dulu. Apabila ada lebih maka bisa dijual sehingga pendapatan keluarga bertambah.

\section{b. Tanaman Pagar}

Tanaman pagar disebut juga pagar hidup, maksudnya pagar yang sengaja dibuat dari tanaman. Tanaman pagar dipilih dari jenis yang dapat dimanfaatkan oleh pemilik. Beberapa tanaman yang sering dijadikan sebagai pagar adalah tanaman mangkokan, puring, petai cina, singkong, puring dan lain-lain. Bagian tanaman ini bisa dimanfaatkan sebagai sayuran, obatobatan maupun bahan bangunan. Selain bisa pemilik bisa memperoleh pendapatan, tanaman ini bisa juga dijadikan penghias rumah yang indah.

\section{c. Tanaman Buah}

Tanaman buahan merupakan salah satu tanaman yang umum ditanam di lahan pekarangan. Tanaman ini dimaksudkan sebagai penghasil buah yang akan dikonsumsi untuk keluarga maupun untuk tujuan komersial. Tanaman buah yang tinggi dan rindang biasanya juga dimaksudkan sebagai peneduh dan pelindung rumah dari cahaya matahari. Buah-buahan yang umum ditanam adalah jambu, jeruk, rambutan, pisang, mangga, strawberi dan lain-lain

\section{d. Tanaman Obat dan bumbu dapur}

Masa kini, paradigma masyarakat berubah menjadi back to nature atau kembali ke alam. Lahgan pekarangan juga bisa dimanfaatkan untuk ditanami tanaman obat. Tanaman ini sangat bermanfaat untuk pengobatan tradisional dan sebagai salah satu bumbu dapur. Tanaman obat yang bisa ditanam di sekitar rumah adalah kunyit, sereh, kencur, jahe, mahkota dewa, tapak dara, kumis kucing dan lain-lain. Bunga ditanam untuk mempercantik pekarangan rumah. Apabila rumah terlihat asri dan nyaman maka anggota keluarga pun akan memperoleh manfaat secara rohani.

\section{METODOLOGI PENELITIAN}

\section{Profil Desa Sungai Iliran}

Desa Sungai Iliran merupakan salah satu desa yang terdapat di Kecamatan Gaung Anak Serka, Provinsi Riau. Memiliki jumlah populasi 1.264 orang dan terdiri atas 5 dusun, yaitu Dusun Suntung, Dusun Siak Besar, Dusun Siak Kecil,
Dusun Bilal,dan dusun yang menjadi pusat dari pemerintahan desa ini, Dusun Teluk Sungka Hilir. Masyarakatnya didominasi oleh suku Melayu dan Banjar.

Wilayah Desa Sungai Iliranmemiliki kondisi geografis yang sekitar $80 \%$ dipenuhi dengan hutan.Wilayah ini jugaterletak berdekatan dengan hilir sungai Kecamatan Gaung Anak Serka.Disepanjang jalan utama, kita akan melihat ada banyakpepohonan sawit, pinang, dan kelapa.Pada jalan utama ini juga kita akan melintasi jembatan penghubung parit-parit mulai dari parit 17 sampai dengan parit 25

Dalam sejarah, Sungai Ilirandulu dikenal sebagaiTeluk Sungka. Nama Sungka berasal dari kata siamang yang dalam bahasa Melayu disebut dengan Ungke. Konon dulunya "Ungke" ditemukan saat pertama kali ingin membuka lahan di daerah sini.Awalnya desa ini dipanggil dengan sebutan "Desa Teluk Si Ungke", namun karena kebiasaan pengucapan masyarakat, desa ini kemudian lebih dikenal dengan nama "Desa Teluk Sungka".

Pada tanggal 1 April 1974, diadakan suatu acara hiburan rakyat yang mengumumkan secara resmi bahwa pusat Desa Teluk Sungka dipindahkan ke Sungai Hilir. Hal ini dilakukan dengan maksud untuk lebih mengembangkan pembangunan ke arah yang lebih maju. Dengan dipindahkannya pusat desa, maka bergantilah nama desa ini menjadi Sungai Iliran dengan Dusun Teluk Sungka Hilir sebagai pusat pemerintahannya, sedangkan daerah lamanya, memekarkan diri sebagaiDesa Teluk Sungka.

Desa Sungai Iliran merupakan daerah yang didominasi oleh penduduk beragama Islam. Pada setiap dusundapat ditemui tempattempat kegiatan keagamaan seperti masjid, musholla, dan TPQ. Budaya tegur sapa juga menjadi hal yang tidak dapat dilepaskan dari masyarakat disini, sehingga dengan begitu silaturahmi bisa terus terjalin erat diantara para kalangan masyarakat.

Desa Sungai Iliran juga memiliki beberapa tempat pendidikan, yaitu PAUD, Madrasah Ibtidaiyah, SD, SMP, dan SMA. Di desa Sungai Iliran terdapat TPQ yang membantu anak-anak untuk meningkatkan bacaan Al-Qur'an mereka.

Desa ini merupakan tempat dari makam salah satu tokoh muslim terkenal dari Hadramaut Arab, yaitu Syekh Maulana Ibrahim. Syekh Maulana Ibrahim bersama dengan Haji Muhammad Shaleh merupakan dua orang tokoh yang pertama kali membangun perkampungan penduduk di daerah Sungai Iliran ini. Keduanya dulunya merupakan orang penting dalam pemerintahan Kesultanan Indragiri. Haji Muhammad Shaleh menjabat sebagai bendahara kerajaan, sedangkan Syekh Maulana Ibrahim sebagai Menteri Agama 
Kerajaan. Namun keduanya pergi meninggalkan Kesultanan Indragiri karena pihak kesultanan terlalu membuka diri dengan pihak Belanda.

Desa Sungai Iliran secara garis beras, terdiri dari wilayah hutan, perkebunan, dan sungai, dimana penduduknya didominasi sebagian besar sebagai penjual dari tiga komoditi utama, yaitu sagu, pinang, dan kelapa.

Sagu, pinang, dan kelapa merupakan sumber utama pendapatan masyarakat Desa Sungai Iliran. Sagu dipanen secara langsung untuk dijual berdasarkan harga yang sesuai dengan beratnya. Pinang juga demikian, pinang dikupas terlebih dahulu untuk diambil isinya, kemudian dijemur dan ditimbang untuk diperdagangkan. Sedangkan untuk kelapa,

Warga Sungai Iliran juga sangat hobi berolahraga. Jika masyarakat pada umumnya lebih hobi bermain bola, masyarakat Sungai Iliran lebih menggemari olahraga voli. Ada banyak lapangan voli disini. Hampir setiap sore setelah selesai menjalani rutinitas harian, mereka menyempatkan diri untuk berolahraga. Namun bukan hanya olahraga voli saja, karena juga ada gor badminton disini yang selalu ramai dikunjungi baik oleh warga sini, maupun dari warga luar desa. Kemudian lahirlah UndangUndang No. 5 Tahun 1979 yang merubah kata Kenegrian menjadi Desa. Dengan demikian, Kenegrian Teluk Sungka kemudian berganti nama menjadi Desa Teluk Sungka, dengan membawa 11 dusun yang pada saat itu dipimpin oleh:

a. Dusun Terjun Jaya(ASamad)

b. Dusun Sungai Hilir (Desa Teluk Sungka) (Yahya. S) Dusun Bunga Mawar (Ismail. M)

Dusun 2 Sekawan (A. Hamid)

Dusun Kejewan (Mahmud Saad)

Dusun Manggis (Makom. Hs)

Dusun Batel (Hamin. HD)

Dusun Teluk Sungka Hilir (Sekarang Desa

Sungai Hilir (Marzuki. W)

Dusun Siak Besar (H. M. Thaib)

Dusun Siak Kecil (Abd. Fatah)

Dusun Suntung (A. Rahman Isa)

Sejarah tentang awal berdiri Desa

Teluk Sungka dan Sungai Iliran ini tidak dapat dipisahkan satu sama lain. Hal ini dikarenakan kedua desa ini berangkat dari latar belakang yang sama, yang membedakan hanyalah profil desa terkini. Setelah terjadi pemekaran yaitu profil masing-masing desa jika diperlukan untuk data-data bagi yang mengeluarkan data bagi dua desa ini.

\section{Gambaran Umum Wilayah}

Desa Teluk Sungka terus berbenah dan melaksanakan berbagai pembangunan di berbagai bidang untuk meningkatkan kemajuan desa.
Dengan luas \pm 6300 ha dan penduduk yang lebih dari 4000 jiwa $\pm 800 \mathrm{KK}$, maka desa ini sudah patut untuk dimekarkan.

Pada tahun 2000, dimekarkanlah dua buah desa, yaitu Desa Teluk Sungka dan Desa Sungai Iliran. Sungai Hilir dipilih sebagai pusat pemerintahan dari Desa Teluk Sungka, sedangkan Teluk Sungka Hilir dipilih sebagai pusat pemerintahan Desa Sungai Iliran.

Adapun Desa Teluk Sungka yang berpusat di Dusun Sungai Hilir, memiliki luas 3000 ha dengan penduduk yang tercatat pada tahun 2012 berjumlah sekitar 2.500 jiwa \pm 500 KK, dengan batas-batas wilayahnya sebagai berikut:

a. Utara dengan Kecamatan Gaung

b. Selatan denga Kecamatan Batang

Tuaka

c. Barat dengan : Desa Tuasan

d. Timur dengan : Desa Sungai

Iliran

Desa Teluk Sungka membawa 6 dusun, yaitu:

a. Dusun Terjun Jaya

b. Dusun Sungai Hilir (Pusat Desa)

c. Dusun Sekawan

d. Dusun Kejewan

e. Dusun Bunga Mawar

f. Dusun Manggis

Sedangkan Desa Sungai Iliran yang berpusat di Dusun Teluk Sungka Hilir, memiliki luas 3.300 ha dengan penduduk yang tercatat pada tahun 2012 berjumlah 1.541 jiwa 379 $\mathrm{KK}$, dengan batas-batas wilayahnya sebagai berikut :
a. Utara dengan: Kecamatan Gaung
b. Selatan dengan: Kecamatan Batang Tuaka
c. Timur dengan: Desa Teluk Sungka
d. Barat dengan: Desa Teluk Pantaian
Desa Sungai Iliran membawa 5 dusun, yaitu
a. Dusun Teluk Sungka Hilir (Pusat Desa)
b. Dusun Siak Besar
c. Dusun Siak Kecil
d. Dusun Bilal
e. Dusun Suntung

Bukti. Bukti sudah diberikan $\square$

\section{HASIL DAN PEMBAHASAN}

a. Kebijakan

Masyarakat serta petani harus berinisiatif untuk memutus rantai covid 19 dengan melakukan aktifitas bertani di pekarangan rumah.

\section{b. Strategi}

Memberikan edukasi atau alternatif kepada masyarakat serta petani untuk bertani di 
pekarangan rumah sebagai alternatif bertani pada masa covid 19.

c. Upaya

Berharap agar alternatif bertani di pekarangan rumah mampu membuat masyarakat mendapatkan keuntungan dari tanaman herbal dan pangan baik sebagai konsumsi maupun penjualan pada masa covid 19

\section{Subjek}

Adapun subjek dari penelitian ini adalah para petani serta warga yang ada di kelurahan Sungai Iliran kecamatan Gaung Anak Serka kabupaten Indragiri Hilir.

\section{$2 . \quad$ Objek}

Yang menjadi objek penelitian ini adalah bagaimana cara petani dan masyarakat umum di kelurahan sungai iliran mampu untuk memiliki tanaman herbal yang menguntungkan karena pandemi covid-19 yang membuat masyarakat kurang melakukan aktifitas seperti biasanya dan mampu memiliki hasil dari bertani di pekarangan rumah sendiri baik untuk konsumsi maupun penjualan.

\section{Metode}

a. Wawancara

Wawancara Dalam penulisan ini, peneliti menggunakan metode wawancara dengan pedoman umum untuk mengumpulkan data dari subjek. Wawancara dilakukan kepada beberapa warga yang berada di kelurahan Sungai Iliran. Dari wawancara maka didapatkan hasil yaitu antara lain:

1. Keterbatasan lahan yang ada membuat warga enggan menanam tanaman di perkarngan rumah.

2. Varietas tanaman yang tidak bergam menjadi alasan masyarakat untuk tidak melakukan bertani di pekarangan rumah.

Dari hasil wawancara tersebut dapat diketahui bahwa masyarakat di Kelurahan Teluk pinang dalam keterbatasan lahan yang ada pada masa covid -19 di pekarangan rumah sudah ada namun hanya saja belum banyak varietas.

b. Diskusi

Diskusi adalah suatu pertukaran pikiran, gagasan atau pendapat antara dua orang atau lebih. Diskusi dilakukan kepada masyarakat dan petani di kelurahan Sungai Iliran ketika metode wawancara telah dilaksanakan. Dalam diskusi peneliti memberikan gagasan dan pendapat mengenai apa itu pertanian halaman rumah dan varietas tanaman yang berbeda pada pertanian halaman rumah baik sebagai konsumsi mau pun penjualan.

\subsection{Gambar}

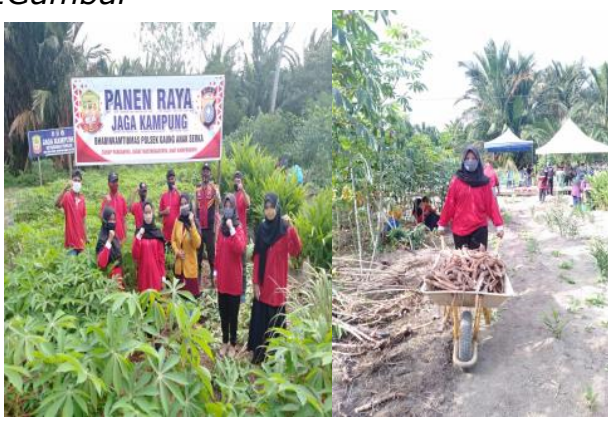

\section{KESIMPULAN DAN SARAN}

Pertanian pekarangan rumah memiliki potensi sebagai alternatif bertani pada masa pandemi covid 19, untuk mencegah aktifitas di luar rumah yang berlebih untuk memutus mata rantai covid 19. Pertanian pekarangan rumah juga dapat membantu masyarakat dalam memanfaatkan lahan yang tidak terpakai menjadi berguna.

Menanam tanaman obat herbal sangat di anjurkan pada masa pandemi covid 19 sebagai penambah imun serta mencegah masyarakat dari penyakit. Untuk produksi sendiri akan mengurangi pengeluaran rumah tangga sehingga dana yang sebelumnya ditujukan untuk kebutuhan sayur atau buah serta tanaman obat dapat dialihkan untuk memenuhi kebutuhan lain atau ditabung. Apabila ada kelebihan maka hasil panen bisa dijual.

Teknologi budidaya yang digunakan bermacammacam. Pemilihan teknologi budidaya disesuaikan dengan selera, kemampuan dan keuangan yang tersedia. Teknologi yang dapat dipilih antara lain tradisional atau modern. Mari kita memanfaatkan pekarangan secara optimal.

\section{Saran}

Kepada seluruh petani Desa sungai iliran.KEC.Gas,untuk tetap melestarikan lingkungan dangan cara, demi bercocok tanaman penghijauan lahan guna untuk melestarikan lingkungan alam dan juga untuk kesehatan lingkungan hidup.Terlebih dimasa pandemi seperti saat ini.

\section{DAFTAR PUSTAKA}

1. Fatma, Pekarangan rumah diakses 12:04 19/09/2020

2. Marshall EJP, Moonen AC. 2002. Field margins in northern Europe: their functions and interactions with 
agriculture. Agric Ecosyst Environ 89:5-

21. 